\title{
Collaboration Across Eight Research Centers: Unanticipated Benefits and Outcomes for Project Managers
}

\author{
Norma A. Perez, MD, DrPH, ${ }^{1}$ Benita Weathers, $\mathrm{MPH}^{2}{ }^{2}$ Marilyn Willis, RN, MS, ${ }^{3}$ \\ and Jacqueline Mendez, $\mathrm{MA}^{4}$
}

\begin{abstract}
Managers of transdisciplinary collaborative research lack suitable didactic material to support the implementation of research methodologies and to build ongoing partnerships with community representatives and peers, both between and within multiple academic centers. This article will provide insight on the collaborative efforts of project managers involved in multidisciplinary research and their subsequent development of a tool kit for research project managers and/or directors. Project managers from the 8 Centers for Population Health and Health Disparities across the nation participated in monthly teleconferences to share experiences and offer advice on how to achieve high participation rates and maintain community involvement in collaboration with researchers and community leaders to achieve the common goal of decreasing health inequities. In the process, managers recognized and seized the opportunity to produce a tool kit that was designed for future project managers and directors. Project managers in geographically distinct locations maintained a commitment to work together over 4 years and subsequently built upon an existing communications network to design a tool kit that could be disseminated easily to a diverse audience. (Population Health Management 2013;16:46-52)
\end{abstract}

\section{Introduction}

$\mathrm{O}$ VER THE YEARS, managers of scientific research projects have played critical roles in the design and successful implementation of multidisciplinary and interdisciplinary research initiatives. Armed with diverse experiences, skills, and professional training, they have supported and promoted a myriad of working relationships, including collaborative efforts, often without the benefit of formal training or mentoring. Federal grantors, including the National Institutes of Health (NIH), are placing increased emphasis on highly sophisticated methodological approaches to develop conceptual models that integrate efforts designed to improve collaboration involving diverse and often complex partnerships within health disciplines, between universities, or with academic institutions, community stakeholders, and leaders. ${ }^{1}$

The 8 Centers for Population Health and Health Disparities (CPHHD) were funded by 4 divisions within NIH to "create environments conducive to interdisciplinary and reciprocally beneficial collaborations among biomedical scientists, social scientists, and affected communities with the common goal of improving population health and reducing health disparities." 2 The CPHHD Project Managers' Working Group (PMWG) emerged in the spring of 2004 during the second annual meeting of the CPHHD, when managers were becoming increasingly aware of the challenges of maintaining their Center partnerships while also playing a more central role in facilitating collaborative efforts across the 8 national Centers. In the process, an unexpected opportunity for collaboration emerged - that of working as a group to develop didactic materials to help novice project managers implement future transdisciplinary research. This article (1) outlines key characteristics and research foci of the Centers in which the project managers operated, reflecting the diversity and potential complexity of the relationships/interactions; (2) highlights collaborative strategies project managers used to develop the tool kit; and (3) presents the key tool kit content areas designed specifically for research project managers as they move increasingly into supporting both multidisciplinary and transdisciplinary research and community-based initiatives.

\footnotetext{
${ }^{1}$ Hispanic Center of Excellence, Office of Student Affairs and Admissions, School of Medicine, University of Texas Medical Branch, Galveston, Texas.

${ }^{2}$ Center for Community-based Research and Health Disparities, University of Pennsylvania, Philadelphia, Pennsylvania.

${ }^{3}$ Community Engagement and Research Core, University of Illinois Center for Clinical and Translational Science, University of Illinois at Chicago College of Nursing, Chicago, Illinois.

${ }^{4}$ Abt Associates Inc, Social and Economic Policy, Cambridge, Massachusetts.
} 


\section{Background and Significance}

Recent advances in how research is conducted have direct implications for project managers. Historically, research originated from individual bench studies, followed by studies that integrated expertise across scientific disciplines and target communities, later known as multidisciplinary, interdisciplinary, and now transdisciplinary research. These research endeavors are complex and varied, and require an understanding of a variety of contributors, including those within disciplines and within academic and nonacademic institutions and organizations. Stokol et al describe various research orientations and name several scientific initiatives that focus on collaborative work to integrate theories, methods, and training strategies in today's collaborative scientific research. ${ }^{3,4}$

To better explore the shared work and common goals between the CPHHD and community stakeholders, it is necessary to assess and understand common risk factors for reducing health inequities as part of the intricacies inherent in collaborative exchange. Gray reported on the challenges of working in a transdisciplinary effort, including coordinating research that incorporates the application of evidence-based medicine to improve health, and understanding the critical role of leadership in the success of transdisciplinary research. ${ }^{5}$ She describes 3 leadership tasks that enhance transdisciplinary collaboration: (1) cognitive tasks such as visioning and framing; (2) structural tasks that consist of team coordination and information exchange; and (3) procedural or process-related tasks commonly known as project management. Currently, transdisciplinary research project management has no "mod$\mathrm{el}^{\prime \prime}$ to follow and few, if any, didactic materials to help guide current or future researchers.

In July 2006, the Economic and Social Research Council conducted a workshop on managing research projects. At the workshop, researchers shared their collaborative work experiences and challenges, emphasizing the lack of available relevant and timely guidance to support the development of project management and collaborative working skills in researchers at all stages of the academic trajectory. ${ }^{6}$ Holmes et al reported challenges experienced during the CPHHD tenure specific to multilevel transdisciplinary research. ${ }^{7}$ This article describes the benefits and outcomes from a collaborative effort bridged from the CPHHD and the CPHHD PMWG, which is reflected in the creation of the tool kit.

\section{CPHHD Initiative}

An overarching goal of the CPHHD was to support cutting-edge research to better understand and reduce the differences in health access, health care, and health outcomes. It soon was decided that each Center should contribute to common measures in addition to pursuing specific individual Center-related goals. These common measures are reflected in Table 1.

In addition, each Center was required to incorporate a community-based participatory component that called for support from community partner initiatives as well as a primary epidemiological project. Table 2 illustrates the diverse community-based research components of each Center and the various epidemiological studies.

All Centers had a unique combination of junior and senior investigators, subcontractors, and community partners who required guidance to meet the challenges of implementing traditional research science in their population-based studies. Project managers were intimately involved in these interactions. In addition, Centers discovered common ground among the research initiatives being conducted, which also may reduce health inequities among populations. Lead investigators and project managers at the Centers worked diligently to establish effective protocols and operating procedures to achieve objectives; the measure of success, however, was not limited to individual Center accomplishments. The diverse and collaborative research agenda at each Center helped to create teamwork between the Centers, and facilitated a unique shared vision for understanding complex field research that addressed health inequities. Figure 1 illustrates the growth process of the initiatives in each Center, which begins with the institutes working autonomously; by the end of the first CPHHD tenure, an active cross-center collaborative has emerged. ${ }^{9}$

\section{Support for Multicenter Collaboration}

From the beginning, grantors established and provided administrative support for key structures to enhance communication and the work of the Centers. These included:

1. A Steering Committee of principal investigators (PIs) at each Center;

2. Working groups that focused on publications, evaluations, community assessments and interventions, communication/Web site, and a cross-center publications group; and

3. A PMWG, initiated as a result of a specific request from project managers. Subsequently, project managers from each Center were invited to join the PMWG and participate in monthly conference calls to receive managerial support in research implementation and dissemination.

Community partners were invited to participate in groups, based on interest. In addition, NIH consultants convened meetings, generated minutes, and ensured that needed follow-up on action items occurred. Most importantly, an $\mathrm{NIH}$ representative was a member of the PMWG and a Center PI routinely participated.

During the monthly calls, logistics, community engagement issues, and data collection processes were discussed, along with managerial, administrative, and other relevant epidemiological field concerns. The conference calls became a source of professional support, and ideas were shared for effective implementation and dissemination of the research. During the second year of funding, the PMWG realized that the unique field experiences and useful information on field research implementation of its members were applicable to various research designs unique to each Center. Project managers were encouraged to document their experiences in a tool kit that could help train managers in transdisciplinary collaborative research techniques. These early years provided the time required for managers, who were virtual strangers, to get to know each other, recognize areas of strength, establish communication strategies, build trust, and test and agree upon group decision-making strategies.

\section{Tool Kit Development}

Managing Human Subjects Research Projects: A Tool Kit for Project Managers ${ }^{8}$ was conceived and written by the CPHHD 
Table 1. Patterns of Research Science Across Center by Research Themes

\begin{tabular}{|c|c|c|}
\hline Measure & Scope of Measure & Centers Utilizing Measure \\
\hline \multirow[t]{2}{*}{$\begin{array}{l}\text { I. Examination of fundamental } \\
\text { causes that determine or are } \\
\text { related to health outcomes }\end{array}$} & $\begin{array}{l}\text { A. Effects of macro level; physical, social, } \\
\text { and policy environments on health and } \\
\text { disease }\end{array}$ & All Centers \\
\hline & $\begin{array}{l}\text { B. Health care systems, families, churches, } \\
\text { community-based organizations, busi- } \\
\text { nesses, legal systems, media, and polit- } \\
\text { ical system }\end{array}$ & All Centers \\
\hline \multirow[t]{2}{*}{$\begin{array}{l}\text { II. Examination of patterns of } \\
\text { social organization that deter- } \\
\text { mine or are related to health } \\
\text { outcomes }\end{array}$} & $\begin{array}{l}\text { A. Impact of neighborhoods, social capitol, } \\
\text { and community organizations on access } \\
\text { and participation in early detection and } \\
\text { health interventions }\end{array}$ & $\begin{array}{l}\text { Ohio State University/University } \\
\text { of Michigan } \\
\text { RAND } \\
\text { University of Illinois } \\
\text { University of Pennsylvania } \\
\text { University of Texas, Medical Branch }\end{array}$ \\
\hline & $\begin{array}{l}\text { B. Social connectedness and social isola- } \\
\text { tion on health disparities }\end{array}$ & $\begin{array}{l}\text { Tufts/Northeastern University } \\
\text { University of Chicago } \\
\text { University of Illinois at Chicago } \\
\text { University of Pennsylvania } \\
\text { University of Texas Medical Branch } \\
\text { Wayne State University }\end{array}$ \\
\hline \multirow[t]{2}{*}{$\begin{array}{l}\text { III. Examination at the individual } \\
\text { behavioral level that deter- } \\
\text { mines or is related to health } \\
\text { outcomes }\end{array}$} & $\begin{array}{l}\text { A. Health behaviors, beliefs, anxiety, and } \\
\text { perceived risk, self-efficacy, readiness to } \\
\text { change, perceived quality of life, and } \\
\text { other personal beliefs about health, risk, } \\
\text { and disease }\end{array}$ & All Centers \\
\hline & $\begin{array}{l}\text { B. Culture and acculturations on health } \\
\text { beliefs, attitudes, behaviors, and per- } \\
\text { ceptions of health and disease to de- } \\
\text { velop health interventions }\end{array}$ & $\begin{array}{l}\text { Tufts/Northeastern University } \\
\text { University of Illinois at Chicago } \\
\text { University of Texas Medical Branch } \\
\text { Ohio State University/University of } \\
\text { Michigan }\end{array}$ \\
\hline \multirow[t]{2}{*}{$\begin{array}{l}\text { IV. Examination of mechanisms/ } \\
\text { pathways that determine or } \\
\text { are related to health outcomes }\end{array}$} & $\begin{array}{l}\text { A. Micro level biological and genetic } \\
\text { mechanisms and their interactions with } \\
\text { social and behavioral determinants of } \\
\text { health and disease }\end{array}$ & All Centers \\
\hline & $\begin{array}{l}\text { B. Socioeconomic status, social stressors } \\
\text { and cumulative wear and tear on organ } \\
\text { systems and allostatic load that con- } \\
\text { tribute to health disparities }\end{array}$ & $\begin{array}{l}\text { RAND } \\
\text { Tufts/Northeastern University } \\
\text { University of Chicago } \\
\text { University of Illinois at Chicago } \\
\text { University of Texas Medical Branch } \\
\text { Wayne State University }\end{array}$ \\
\hline
\end{tabular}

project managers, each one responsible for day-to-day program implementation at their respective Centers. The tool kit, written during years 2 through 4, was based on the managers' research expertise and was supported by representatives from NIH and by the CPHHD's steering committee. The spirit of collaboration was prevalent in the development of the tool kit, which began with a "suggestion/ vision" expressed by a CPHHD PI. After discussion, the group agreed to commit to producing a tool kit. The thenchair of the PMWG willingly assumed a leadership role and drafted and circulated the general content outline of what was then called a handbook. Writing groups were established based on individual experiences and interest in specific topics.

Groups were both multidisciplinary and multiinstitutional. What was immensely rewarding was the respect with which comments from PMWG members from varied backgrounds were received; ultimately, decisions were made based on the commitment to the "higher good."
Without formal discussion and extensive operating guidelines, project managers assumed the collaborative roles required to assure success and guarantee the desired outcomes. Input was obtained, documents shared, and deadlines met. Regular discussions about the content of the handbook made it clear that the document could be expanded into a "living document" that would include the basic tools needed to manage transdisciplinary research projects, to be used for didactic purposes as well; hence, it became known as a tool kit.

\section{Tool Kit Contents}

Table 3 provides an overview of the topics included in the tool kit, which were tailored to the ongoing needs of the CPHHD. The tool kit consists of 6 main chapters that address the most common issues observed during the first CPHHD tenure. Community engagement was the first 


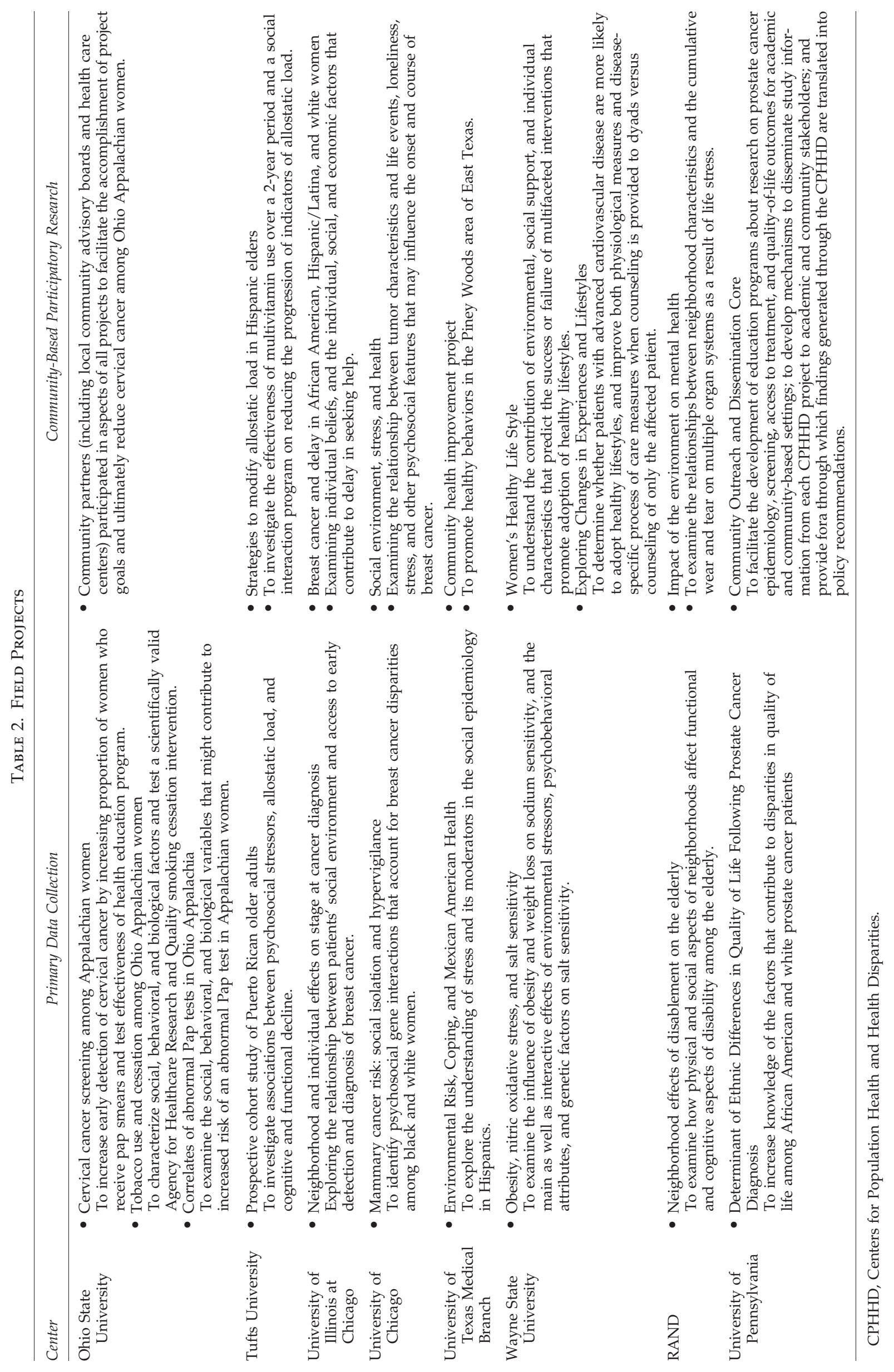



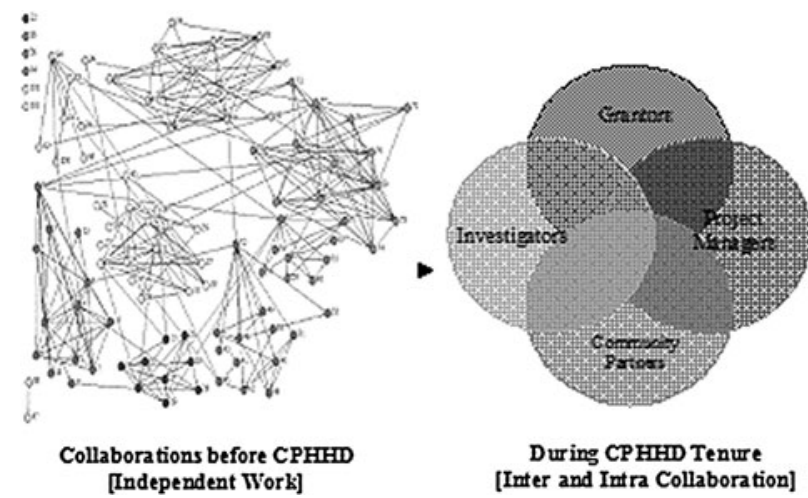

topic addressed after staffing because it was clear from the outset that attention to the community partnership (including building and maintaining a rapport with community stakeholders and leaders) was critical for implementing community-based participatory research programs.

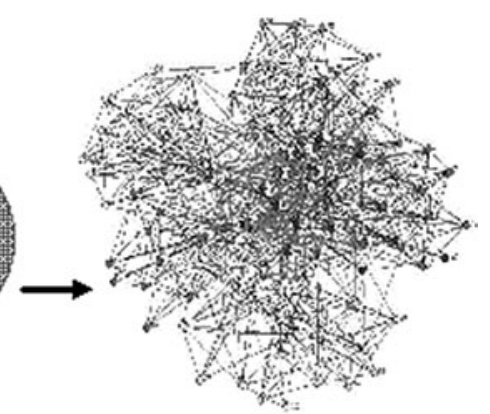

Affer CPHHD [Enhanced Collabor ations]
FIG. 1. Collaborative Leaders. Reference: National Institutes of Health, Centers for Population Health and Health Disparities Society, http://cancercontrol .cancer.gov/populationhealth centers / cphld/documents / CPHHDreport.pdf. See above link for color figure and key. **Dots in upper left corner represent researchers with no ties to others in the network.

\section{Evaluation of the Tool Kit}

Through skillful collaboration, the PMWG completed a first draft that was circulated throughout the Centers, and invited target audiences and peers not involved with the

Table 3. Chapter and Topic Addressed in Tool Kit

\begin{tabular}{|c|c|c|}
\hline Chapter & Topics & Summary \\
\hline $\begin{array}{l}\text { I. Staffing research } \\
\text { projects }\end{array}$ & $\begin{array}{l}\text { 1.1 Hiring staff } \\
\text { 1.2 Orienting and training staff } \\
\text { 1.3 Supervising staff } \\
\text { 1.4 Delegating responsibilities } \\
\text { 1.5 Increasing staff motivation }\end{array}$ & $\begin{array}{l}\text { Chapter describes initial logistical } \\
\text { processes needed to start the project } \\
\text { once funded, and to successfully execute } \\
\text { the research project. }\end{array}$ \\
\hline $\begin{array}{l}\text { II. Involving } \\
\text { community } \\
\text { members in health } \\
\text { research }\end{array}$ & $\begin{array}{l}\text { 2.1 Involving community members in the research } \\
\text { process } \\
\text { 2.2 Recruiting community advisors } \\
\text { 2.3 Interacting with community partners } \\
\text { 2.4 Promoting research study } \\
\text { 2.5 Linking community with resources } \\
\text { 2.6 Disseminating research findings to the community } \\
\text { 2.7 Establishing and maintaining university/community } \\
\text { subcontracts }\end{array}$ & $\begin{array}{l}\text { Chapter describes ways to establish and } \\
\text { build rapport with community } \\
\text { stakeholders and leaders. }\end{array}$ \\
\hline $\begin{array}{l}\text { III. Review } \\
\text { regulatory } \\
\text { guidelines for } \\
\text { human subjects } \\
\text { research }\end{array}$ & $\begin{array}{l}\text { 3.1 The Federal Institutional Review (IRB) Guidebook } \\
\text { 3.2 The Office for Human Research Protections } \\
\text { Policy Guidance } \\
\text { 3.3 The Health Insurance Portability and Accountability } \\
\text { Act of } 1996 \\
\text { 3.4 Working with the Office of Protection for Research } \\
\text { Subjects at your institution } \\
\text { 3.5 Attending ethics and human subjects training } \\
\text { 3.6 Submitting and maintaining IRB approval } \\
\text { 3.7 Reporting and identifying adverse events }\end{array}$ & $\begin{array}{l}\text { Chapter provides electronic links to } \\
\text { institutional and federal research } \\
\text { guidelines. }\end{array}$ \\
\hline $\begin{array}{l}\text { IV. Fielding research } \\
\text { projects }\end{array}$ & $\begin{array}{l}\text { 4.1 Managing data collection } \\
\text { 4.2 Recruiting and retaining respondents } \\
\text { 4.3 Reviewing data quality } \\
\text { 4.4 Collecting biological samples }\end{array}$ & $\begin{array}{l}\text { Chapter depicts day-to-day duties of } \\
\text { managing primary and secondary data } \\
\text { collection projects. }\end{array}$ \\
\hline $\begin{array}{l}\text { V. Preparing for data } \\
\text { collection }\end{array}$ & $\begin{array}{l}\text { 5.1 Establishing study design, timeline, and budget } \\
\text { 5.2 Designing study questionnaire and qualitative data } \\
\text { guides } \\
\text { 5.3 Drafting and documenting research procedures } \\
\text { 5.4 Developing a study procedures manual and codebook } \\
\text { 5.5 Effective communication and meeting facilitation } \\
\text { strategies }\end{array}$ & $\begin{array}{l}\text { Chapter details preparatory processes for } \\
\text { tasks before, during, and after conduct- } \\
\text { ing field activities. }\end{array}$ \\
\hline $\begin{array}{l}\text { VI. Finalizing data } \\
\text { collection }\end{array}$ & $\begin{array}{l}\text { 6.1 Collecting post-interview data } \\
\text { 6.2 Preparing final deliverables } \\
\text { 6.3 Preparing methodological report } \\
\text { 6.4 Reporting study outcomes }\end{array}$ & $\begin{array}{l}\text { Chapter discusses common issues found } \\
\text { after the data collection process has } \\
\text { been completed, from collecting } \\
\text { post-interview data to reporting study } \\
\text { outcomes. }\end{array}$ \\
\hline
\end{tabular}


Centers to provide feedback to further refine the tool kit. The PMWG received feedback from 4 non-CPHHD project managers who had an average of 5 years of managing experience; 2 of the managers had graduate degrees. All agreed to provide regular feedback if the tool kit were to become Web-based; 3 project managers thought that it could be considered a necessary training tool. Comments included: "I would be glad to add tools that I found successful, such as community involvement," "The tool kit is a very comprehensive resource," and "Great resource for new field project managers." Upon receipt of the feedback, the tool kit was finalized and placed on the NIH CPHHD Web site ${ }^{8}$ and the CPHHD portal for users to access.

Currently, the PMWG is in the process of developing a program in conjunction with the NIH to maintain the Web-based tool kit by including continual user feedback. The comments or updates are expected to be incorporated into the tool kit by the NIH CPHHD Web site ${ }^{2}$ administrators to aid current and future research project managers.

\section{Lessons Learned}

This article briefly describes the benefits of inter- and intra-collaboration among the CPHHDs, which were reflected during the development of the tool kit. From the start, project managers envisioned the tool kit as a possible didactic guide to train novice project managers as they participated in multilevel transdisciplinary research project management.

In addition, the PMWG proved that multidisciplinary and distant team science initiatives are possible through teleconferencing. As circumstances demanded, project managers were willing to assume a variety of leadership and critical support roles to ensure the successful completion of the tool kit project. The annual meetings also helped build trust.

\section{Conclusion}

The CPHHD's first tenure proved that collaboration among peers was essential in the development of the tool kit. This collaborative experience and the subsequent findings suggest that further research is needed to better understand the vital role that project managers perform before, during, and after a grant is awarded. These findings should offer greater insight into the distinctive role that project managers play in future research project management and direction. As transdisciplinary research becomes more commonplace, it is imperative to develop instructive materials to train research project managers to manage complex team science initiatives that may reflect a true model of transdisciplinary, multidisciplinary, and interdisciplinary research project management.

The tool kit represents the first step toward making materials available that will move the science of managing transdisciplinary research projects forward more effectively and efficiently. The tool kit also offers the scientific community a better understanding of the varied and integral roles that research project managers play throughout the study trajectory. It also may enhance project managers' skills and abilities to facilitate project implementation. A structured evaluation of the tool kit should be conducted to better refine and assess its usefulness and effectiveness for training research project managers.

\section{Acknowledgments}

The authors acknowledge the support of the principal investigators from each Center; Shobha Srinivasan, Ph.D., for her continued support in publishing this article; Richard Warnecke, Ph.D., for his continued support during the conference calls and for his multiple revisions to the manuscripts; Nanci Hemberger for her editorial contributions to the paper and managerial skills in organizing our teleconferencing meetings; and Sarah Toombs-Smith, Ph.D., E.L.S., for the final editorial revision.

The authors also acknowledge the authors of the tool kit: (listed in alphabetical order)

Jill Abbott, M.P.H., Dr.P.H., Ohio State University

Cecelia DeGraffinreid, M.H.S., R.H.I.A., Ohio State University

Amanda Dudley, B.S., Wayne State University

Maria Ferra, M.S.W., University of Chicago

Patty Kuun, M.A., C.H.E.S., Ohio State University

Jackie Mendez, M.A., Tufts University

Leda Munoz Orians, Tufts University

Norma A. Perez, M.D., Dr.P.H., University of Texas Medical Branch at Galveston

Courtenay Savage, The University of Chicago

Cathy Tatum, M.A., Ohio State University

Benita Weathers, M.P.H., University of Pennsylvania

Marilyn Willis, R.N., M.S., University of Illinois at Chicago

\section{Author Disclosure Statement}

Dr. Perez, Ms. Weathers, Ms. Willis, and Ms. Mendez disclosed no conflicts of interest regarding the research, authorship, and/or publication of this article. The authors have no competing financial interests.

\section{References}

1. Himmelman AT. Collaboration for a change: Definitions, decision-making models, roles, and collaboration process guide. Available at: www.depts.washington.edu/ccph/pdf_ files/4achange.pdf. Accessed April 18, 2012.

2. National Institute of Environmental Health Sciences. Centers for population health \& health disparities. Available at: www .niehs.nih.gov/research/supported/centers/disparities. Accessed April 18, 2012.

3. Stokols D, Hall KL, Taylor BK, Moser RP. The science of team science: overview of the field and introduction to the supplement. Am J Prev Med 2008;35:S77-S89.

4. Stokols D, Misra S, Moser RP, Hall KL, Taylor BK. The ecology of team science: understanding contextual influences on transdisciplinary collaboration. Am J Prev Med 2008;35: S96-S115.

5. Gray B. Enhancing transdisciplinary research through collaborative leadership. Am J Prev Med 2008;35:S124S132.

6. Brown A. Managing research projects. Presented at: Economic and Social Research Council Research Methods Festival; July 17-20, 2006; Oxford, United Kingdom. 
7. Holmes JH, Lehman A, Hade E, et al. Challenges for multilevel health disparities research in a transdisciplinary environment. Am J Prev Med 2008;35:S182-S192.

8. National Institutes of Health, Centers for Population Health and Health Disparities. Managing human subjects research projects: A tool kit for project managers. Available at: http:// cancercontrol.cancer.gov/populationhealthcenters/cphhd/ toolkit.html. Accessed April 19, 2012.

9. Centers for Population Health and Health Disparities. Cells to society: overcoming health disparities. Available at: http:// cancercontrol.cancer.gov/populationhealthcenters/cphhd/ documents/CPHHD_report.pdf. Accessed April 19, 2012.
Address correspondence to: Norma A. Perez, M.D., Dr.P.H.

Hispanic Center of Excellence Office of Student Affairs and Admissions Ashbel Smith Building, Room 1.206 School of Medicine University of Texas Medical Branch 301 University Blvd Galveston, TX 77555-1308

E-mail: noaperez@utmb.edu 